\title{
Irish Accents, Foreign Voices: Mediated Agency and Authenticity in In the Name of the Father and Fifty Dead Men Walking Nicole Ives-Allison*
}

\begin{abstract}
Given the intensity of narrative contestation over the public history of and discourse around the modern period of Northern Irish civil conflict known locally as 'the Troubles', for filmmakers from outside of Northern Ireland to be seen as making a legitimate contribution to existing debates, there is a pressure for their film texts to be read as 'authentic'. This desire for authenticity fundamentally shapes the narrative approach taken by these filmmakers. Various filmmaking strategies have been employed in the pursuit of authenticity, but both Jim Sheridan's In the Name of the Father (1993) and Kari Skogland's Fifty Dead Men Walking (2008) have taken a distinctly narrative approach, relying upon local written autobiographical material. However, the way in which Sheridan and Skogland have sought to deploy the authenticity embedded in locally grounded source material flirts with self-defeatism as both films problematically obscure the limitations on agency imposed by the filmmakers on the local voices upon who claims of authenticity, and thus the films' legitimacy, depend.
\end{abstract}

Both In the Name of the Father (Jim Sheridan, 1993), based on Gerry Conlon's 1991 autobiography Proved Innocent: The Story of Gerry Conlon, and the Guildford Four and Fifty Dead Men Walking (Kari Skogland, 2008), based on Martin McGartland's 1997 eponymous memoir, provide interesting case studies for how authenticity and agency are negotiated and managed in the creation of films dealing with Northern Ireland's recent troubled past.' The central argument of this paper is that by grounding their films in the autobiographies of individuals directly involved in the Troubles-related events depicted on screen, both Sheridan and Skogland effectively tap into the

\footnotetext{
1 Over the course of thirty years, between 1968 and 1998, Northern Ireland experienced a period of low-intensity civil conflict with political violence, specifically that committed by the Provisional IRA (an illegal paramilitary organisation which was committed to pursuing the reunification of Ireland through violent means), emanating outwards and affecting the British mainland and the Republic of Ireland. A strong selection of some of the most concise and comprehensive overviews of the conflict include: Bew, Gibbon, and Patterson, 2002; Bew and Gillespie, 1999; McKittrick and McVea, 2012; Mulholland, 2003; Tonge, 2006; Whyte, 1991.
}

* Nicole lves-Allison is a second-year PhD Candidate in International Relations with the Handa Centre for the Study of Terrorism and Political Violence at the University of St Andrews. Her research focuses on interdisciplinary undrstandings of political violence, from the role of inequality in its mitigation to its filmic representations. 
proximiity-based authenticity of the local written narratives as a means of strengthening the perceived authenticity of their respective films. However, in doing so these two films problematically obscure the process of mediation all written material undergoes as it is translated from page to screen, whether it be a book as source material or even the final version of a film script. With the filmmaker as chief mediator, this process necessarily limits the exercise of agency by those local voices who underpin each film's claims of authenticity. Though the mediation process which is common of, if not essential to, narrative filmmaking is not problematic in and of itself, that In the Name of the Father and Fifty Dead Men Walking, render its presence largely invisible is quite worrisome. In concealing the hand of the filmmaker these films risk seriously undermining the authenticity that gives their narratives legitimacy within a contested narrative terrain. Furthermore, it is only through an understanding of how agency is mediated in the creation of each filmic narrative that it becomes possible to discern how the filmmaker's understanding of (1) the events on screen, (2) the film's social and political context, and (3) broader aesthetic and/ or philosophical concerns, shape what is seen by audiences as the finished product.

Narratives are first and foremost battlegrounds. From esteemed historical tombs to contemporary romantic comedies, it is in narratives that our individual and collective perceptions of reality are forced to confront events as they may have materially occurred. Along narrative front lines various versions of the truth compete for the dominance that lies in the sheer act of being recorded and presented to the world, with the dissemination of one's own version of events reinforcing the perceived legitimacy of that particular understanding. In "The Value of Narrativity in the Representation of Reality," Hayden White argues, "If we view narration as the instrument by which the conflicting claims of the imaginary and the real are mediated, arbitrated, or resolved in a discourse, we begin to comprehend both the appeal of the narrative and the grounds for refusing it." (White, 1980: 8-9) For those narrative forms aspiring to realism, as is the case with both films under study here, the battle becomes even more intense as notions of 'authenticity' are bound up with ideas about 'truth' and 'reality'. More intense still are the battles around those narratives surrounding 'contested' or 'controversial' events where internal struggles for self-consistency take place within a full-scale war for legitimacy among competing, and frequently irreconcilable overarching narratives. Where the rewards for being the 'prevailing truth' among a range of divergent narratives are particularly high, it is the links between narrative consistency, 
truth, reality and authenticity that carry paramount importance. For those filmmakers who have found narrative inspiration in the Troubles of Northern Ireland, the war for narrative truth in which they have enmeshed themselves is particularly intense. With the initial seeds of conflict dating back variously from the twelfth century 'invasion' of Ireland (O'Leary, 1896: 78) to the seventeenth century plantation of Ulster, ${ }^{2}$ (Darby, 1995: 16; Mulholland, 2002) continued tensions between the region's two main ethnic, religious, and political communities have lent weight to the impression that conflict in Northern Ireland is intractable. (Coleman, 2003: 28) Thus, it is unsurprising that there are numerous antagonistic overarching narratives of the conflict. While there are often many factual details shared between the versions of events offered by the majority (religiously Protestant, politically largely unionist/loyalist) and minority (religiously Catholic, politically largely nationalist/republican) communities in Northern Ireland, such as date, time, number of persons affected, interpretations of the intent and significance of events commonly verge on the mutually exclusive. ${ }^{3}$ Frequently these narratives also come into conflict with the 'official' record of events provided by the government, with official records forming a narrative of their own that runs the risk of being reappropriated by either (or both communities) as leverage in their own zero-sum game for political control. (Smithey, 2009: 86-87)

This puts filmmakers dealing with Northern Ireland in a rather difficult position, for the numerousness of existing narratives and the resoluteness of the positions of the two main communities means that

2 Ulster is one of the four historic provinces of Northern Ireland, originally consisting of nine counties. When the island was partitioned under the Government of Ireland Act, 1920 in the run up to independence for southern Ireland, the six counties of Ulster in which there was a Protestant majority became Northern Ireland and remained as part of the United Kingdom. Contemporarily, the terms Ulster and Northern Ireland are used interchangeably by the majority unionist community, with the minority nationalist communitiy commonly referring to the region as "the north" or "the six counties". The 'plantation of Ulster,' refers to the large-scale settlement of the province by British Protestants and is offered as historic root of the modern Northern Irish conflict by scholars John Darby, Marc Mulholland, and David Smith \& Gerald Chambers. (Darby, 1995: 16; Mulholland, 2002; Smith and Chambers, 1991)

3 Perhaps nowhere is this penchant for contradictory narratives more strongly seen than in discussions around Bloody Sunday, with the Protestant community initially adopting the original official (government) version of events as its truth and the Catholic community constructing a radically different counter narrative. Since the end of the Troubles, there has been a noticeable shift in the government's official narrative of the events of that day as the decade-long Bloody Sunday Inquiry (also known as the Saville Inquiry) exposed major holes in the original official record. By the release of the Inquiry's report in 2010, the official record accepted much of the Catholic community's version of events, including that all fourteen of those killed by the British Parachute Regiment on the day of 30 January 1972 were unarmed and not engaged in offensive action at the time of their deaths. (Conway, 2003: 305-320; Dawson, 2007: 87-205; Saville, 2010) 
even before any film dealing with Northern Ireland opens in cinemas, it risks alienating a sizeable portion of the local population on the basis of perceived sympathies alone. Yet, rather than shying away from producing films about Northern Ireland, filmmakers have found the Troubles to be a fertile narrative terrain from which melodramas, ${ }^{4}$ comedies, ${ }^{5}$ thrillers ${ }^{6}$ and action films ${ }^{7}$ have sprung. Where making films capable of securing strong support from both political communities remains a near impossible quest, filmmakers have instead sought to create their own narratives of the conflict which, while drawing upon existing personal and community narratives, can also be considered to exist independently from the main narrative camps. While in theory, given the number of films using the Troubles as subject matter, this should mean that narratives from both communities are well represented, in practice Protestant narratives have largely been ignored. (Barton, 2004: 159; Donnelly, 2000: 390; Hill, 2006: 197; Mcllroy, 2001: 11, 199-200; McLoone, 2000: 79-83; Pettitt, 2000: 261) The reasons offered for what can be seen to be a nationalist focus bias are both numerous and varied, ranging from the political sympathies of filmmakers and a lack of Protestant filmmakers to a belated realisation on the part of the part of the unionist community of its need to communicate beyond its own community. (Mcllroy, 2001: 18-27) As a result, rather than remaining above the narrative politics of the conflict filmmakers have embedded themselves within them, albeit with varying degrees of pro-activeness. In doing so, filmmakers enter into a competition with existent community and official narratives over both legitimacy and supremacy.

'Troubles film' filmmakers, like all those working in the area of historical film, face considerable pressure to create films which are both realistic and truthful. (Higashi 1995, 200; Rosenstone, 2006: 20) Because of its entanglements with both realism and truth, authenticity becomes the key to their achievement. JP Roos has argued that, "An authentic story is authentic because it refers to something: it stands in authentic relation to actions, events and social reality." (Roos, 2003: 34) But how does a narrative stand in authentic relation to on-screen events? Karen Golden-Biddle and Karen Locke argue that proximity is the key marker of authenticity, with the ability to stand in 'authentic relation' derived from having 'been there', a perspective echoed by Roos himself. (Golden-Biddle and Locke, 1993: 598-600; Roos, 2003: 344 For example In the Name of the Father (Jim Sheridan, 1993) and Some Mother's Son (Terry George, 1996).

5 Such as An Everlasting Piece (Barry Levinson, 2000).

6 For example Shadow Dancer (James Marsh, 2012) and Fifty Dead Men Walking (Kari Skogland, 2008).

7 Such as A Prayer for the Dying (Mike Hodges, 1987). 
35) However, the proximity privilege that underlies this understanding of authenticity presents a problem for those filmmakers seeking to engage with the Troubles who, coming from outside Northern Ireland, lack first-hand experience of the events they are representing. Some filmmakers have actively sought to overcome this barrier by peopling their cast with local and/or 'non-professional' actors, as has been the case with Sunday (Charles McDougall, 2002), Bloody Sunday (Paul Greengrass, 2002), and Omagh (Pete Travis, 2004). (Sutherland, 2010: 267-281) In Bloody Sunday, Greengrass also employed a documentary aesthetic and hand-held camera techniques in his pursuit of realism and authenticity. (Blaney, 2007: 113-138) However, with In the Name of the Father and Fifty Dead Men Walking, Jim Sheridan and Kari Skogland instead work to imbue their films with authenticity through their use of local autobiography as source material.

\section{Mediated Agency: The Limits of Representational Self-Control}

Before it is possible to illustrate how exactly these two films work to conceal the mediation of agency, it is worth outlining 'mediated agency' as a concept in its own right. ${ }^{8}$ For our purposes mediated agency can be defined as the process in which a dominant author grants (or gives the impression of granting) the represented negotiating power over their representation, with the actual expression of this power constrained and limited by the dependence of the represented on the author as the intermediary between their narrative voice and the audience. The dominance of the filmmaker referred to in this definition is not in related to his/her broader social, political or economic positioning and applies only to the limited confines of the production of the film text. The filmmaker, or director, is in a position of dominance vis-à-vis the represented in a fictional narrative film because, to use a rather auteurist idea of authorship, it is the filmmaker who bears ultimate responsibility for the finished film and, by extension, the construction and dissemination of a 'final' representation. Mediated agency operates whether or not the filmmaker is consciously aware of its existence, and while its effects may be more or less keenly felt,

8 Which should not be confused with the concept of mediated agency put forth for use in developmental psychology by James $V$ Wertsch and Leslie J Rupert. (Wertsch and Rupert, 1993).

9 Underpinning auteur theory is the idea that it is the filmmaker, generally defined as the director in the case of narrative fiction filmmaking, who is the author of a film text and who bears both responsibility for and control over the film production. Though the applicability of auteur theory to a Hollywood filmmaking context requires substantial adaptation due to the prominence of the studio system, as both films under examination here were produced outside of Hollywood, applying auteur theory to a reading of these film texts does not carry the same difficulties. (Caughie, 1981; Corrigan, 2003; Hess, 1974) 
its presence can be seen even in those works which attempt to grant the represented a high degree of control over their representation. Because of its subtlety it can often go unrecognised by the filmmaker and its existence is independent of any aesthetic or political ideology or agenda. In and of itself mediated agency is benign, but where its existence is concealed the power dynamics between filmmaker and represented are denied, undermining the voice of the represented and rendering 'agency' largely illusory, though not destroying it entirely. Where agency is a but an illusion, the validity of the author's claims of authenticity, and in turn truthfulness and realism, are eroded. Thus, it is not the existence of mediated agency, but how it is handled by each individual filmmaker within the context of each individual film text that can present problems for a film's ability to present itself as authentic, truthful and real.

It is tempting to argue that where the mediation process is effectively concealed, the viewer could perceive the voices of the represented as carrying something near total legitimacy, but such a counter-argument would depend on an understanding of the audience as passive and uncritical audience, accepting each image, sound and movement as undeniably true. However, this conception of the passive audience is so extreme that it is unlikely to find much favour beyond the most radical advocates of the work of Theodor Adorno and Max Horkheimer, interpretations of these writings themselves dismissed for their simplicity and inherent elitism. (Hills, 2002: 31; Hollows, 1995: 221-222; Moore 2010: 203-204) More tenable a view is that put forth by Jeffrey Richards who argues that, "the relationship between film and audience is reciprocal. An audience does not passively accept every message that is put across in a film. For one thing, it can choose which films to see and which to avoid. Even within films it can accept elements that it likes and reject unpalatable ones." (Richards, 1996: 399)

So much as an audience may enter into agreement with the filmmaker to cede the inclination to immediately scrutinize every trace of presented reality for the sake of full immersion into the narrative, even the willing suspension of disbelief has its limits. (Ferri, 2007: 3546) With the audience fully cognizant that what they are consuming is a film as opposed to unfiltered reality, regardless of whether this is a fact explicitly discussed within the filmic text, reflexivity (including self-reflexivity) and realism need not be mutually exclusive. Indeed, "Rather than strictly opposed polarities, realism and reflexivity as interpenetrating tendencies are quite capable of coexisting within the 
same text." (Stam, Burgoyne and Flitterman-Lewis, 1992: 206) In this light it becomes possible to argue that the obfuscation of mediated agency is not necessary for a film to succeed on an immersive level. Furthermore, given the problems for authenticity created by such concealment, acknowledgement of the mediation which occurs in bringing 'authentic' voices to the screen can be seen as a key to enduring narrative legitimacy.

\section{Framing and Fidelity in In the Name of the Father}

Turning to the case studies at hand, in addition to rooting their claims to authenticity in their autobiographical source material, In the Name of the Father and Fifty Dead Men Walking are examples of critically and commercially successful Troubles films directed by filmmakers from outside of Northern Ireland. Rare among those dealing with the Troubles, both films were able to secure a strong international audience, though of the two it is the multiple Academy Award-nominated In the Name of the Father that stands alongside Neil Jordan's The Crying Game (1992) as the most globally successful film treatment of the conflict in Northern Ireland. The work of Dublin filmmaker Jim Sheridan, In the Name the Father is a compelling melodrama which explores the wrongful convictions of the Guildford Four and Maguire Seven in relation to the bombings of two pubs in Guildford, Surrey, England by the Provisional Irish Republican Army in October 1974. In the Name of the Father foregrounds its claim to authenticity through its explicit expression in the form of a title card in the film's opening credits reading, "Based on the Autobiographical Book PROVED INNOCENT by Gerry Conlon." Yet, it is the implicit claim to authenticity embedded in the framing of the film which proves to be most powerful. Utilising a frame story in which the fictional Conlon serves as the film's narrator, the events of In the Name of the Father span fifteen years from the summer of 1974 leading up to the Guildford bombings until the 19th of October 1989 when the convictions of the Guildford Four were overturned.

The use of a frame story, sometimes referred to as a 'frame narrative' is significant for, as argued by Winifred Morgan, "The frame's primary purpose is to vouch for the veracity of the events or narrator of the inner story." (Morgan, 2002: 282) Given the complexities in directly transposing literary narrative modes with filmic ones, it is possible to argue that in the case of In the Name of the Father, the use of a frame story means that Conlon is both outer and inner narrator. This leaves the diegetic Conlon responsible for establishing the credibility of his own 
narrative of events in a film text where self-reflexivity is suppressed and the hand of Sheridan as filmmaker is hidden. Additionally, because of Conlon's position as both outer and inner narrator, he also takes on the role of diegetic mediator. It is through him that all other voices must pass, from his father and Paul Hill through to the police officers who mistreat him, even where he is not directly privy to conversations and events.

Covering the whole fifteen-year period depicted in the film, the inner story takes the form of Gerry Conlon recounting his tale of how he came to be convicted of, and imprisoned for, crimes he did not commit to his lawyer Gareth Pierce via audio-tape. He begins his version of events with a description of his life in Belfast as it was before he fatefully left for England to try his fortune in the autumn of 1974. He describes how his life of petty crime led to a serious run-in with the Provisional IRA who had taken upon themselves the role of 'community police' in his West Belfast neighbourhood. Fearing for his safety,

Conlon's family implores him to move to England to pursue a legitimate career. The story carries through the time he spends living in a North London squat, followed by a night in a hotel and a return home funded by the break and enter robbery of a prostitute's boudoir. Quickly after his return, Conlon is arrested and held under the newly passed Prevention of Terrorism Act, 1974, which extended the acceptable length of detention without trial from two to seven days. (Nunes, 2009: 917) After being flown to England for interrogation, he is tortured into signing the confession which will serve as the only evidence linking him to the Guildford bombings for which he and his friend Paul Hill are swiftly convicted (along with acquaintances Paddy Armstrong and Carole Richardson).

As a result of questionable information provided under duress several members of Conlon's extended family, including his father Guiseppe, are also arrested, detained and wrongfully convicted for the possession of the explosive materials allegedly used to make the bombs. This group becomes collectively known as the Maguire Seven, derived from the surname of Conlon's aunt, uncle and young cousins. Much of the film is focused on the time Colon spends in prison rebuilding his relationship with the eternally optimistic Guiseppe who refuses to passively accept what, for him at least, will be a life sentence. Despite failing health, Guiseppe dedicates much of his energy to a letter writing campaign which, following his death in 1980, is taken up by Gerry. After his father is no longer able to take the stairs required to attend meetings, it is Conlon who also begins to meet with Pierce 
to discuss the possibilities for launching a new appeal. It is at this point where the events of the story frame catch up with those of the diegetic frame which forms the film's 'present day', focusing on the preparation of the appeal which will lead to the quashing of the original verdict.

It is essential when discussing film adaptations to avoid the temptation to assess a film text by its fidelity to the source text alone. A film is not a book and must not be judged according to the standards applied to written texts. In addition to being a medium which is both auditory and visual, film is a medium of motion that tasks the filmmaker with filling an ever-present and shifting field of vision with only those objects which will serve to maintain the illusion of reality. (Herlihy, 1988: 1189; Metz, 1974: 7) But when, like with In the Name of the Father, the film under consideration is one whose legitimacy is dependent upon its maintenance of a perception of authenticity underpinned by its use of written autobiographical source material, fidelity is perhaps a fairer grounds for appraisal than would otherwise be the case. At the same time, the grounding of In the Name of the Father in the 'real' Conlon's Proved Innocent means that the film presents 'Conlon' not only as diegetic mediator and inner/outer narrator but external narrator as well. As all voices must ultimately pass through various versions of 'Conlon' at four different levels in addition to passing through Sheridan as filmmaker, the capacity of In the Name of the Father to engage in the type of credible complex historical, social and political analysis of the events depicted on screen that is the substance of traditional academic debate is severely limited. Where the film has attempted to deal with events of which Conlon lacks first hand knowledge, such as in the brief scenes depicting the Provisional IRA unit's final preparations for the Guildford pub bombing, these explorations can be seen as mounting a challenge not just to the historical record, but to the film's authenticity as well. Of the two preparation scenes, the second (and most substantial) presents the attack as being an impulsive response to the breakdown of a Provisional IRA ceasefire and a subsequent heavy handed incursion into to the Catholic Ardoyne area of north Belfast. That this is wholly inaccurate given the absence of a ceasefire at the time of the events depicted is less of a concern than the way in which these scenes, and the film as a whole, detaches the Guildford pub bombing from the larger Provisional IRA mainland bombing campaign waged throughout 1973-1974, including the pub bombings in Woolwich and Birmingham. (Bew and Gillespie, 1999: 47-109; Gillespie 2010: 64; McKitrick et al, 2001: 480; Oppenheimer, 2009: 75-81)

With two of the Guildford Four, Paul Hill and Paddy Armstrong, 
also held responsible for the Woolwich bombing and the wrongful convictions of six men for the Birmingham bombings representing an additional gross miscarriage of justice, such complete detachment is quite worrisome given the power that Sheridan's film text has wielded in public discourse around the Guildford pub bombings. While it has been argued that this series of attacks was, in some ways, the Provisional IRA's response to being put on the defensive by Operation Mortarman and the strong military response to Bloody Friday, (Oppenheimer, 2009: 76) the timing of the bombings means that it is perhaps more appropriate to see them as part of a strategic offensive with the goal of arousing English public opinion. (English, 2003: 169; Oppenheimer, 2009: 75-76) While the simplicity with which Sheridan depicts the planning process is not entirely surprising given the larger inconsistencies between the film and the historical record, it does serve as an example of how mediated agency is able to manipulate, consciously or unconsciously, the public history of events by embedding shaky claims to truth and authenticity within broader more palatable ones. Because of the inaccuracy and, arguably, misrepresentation here, one must wonder whether it is possible to place any trust at all in those details which lie outside of the experiential scope of 'Conlon' as inner, outer and external narrator, despite the reality that it is Sheridan, who lacks proximity to any of the events depicted, who holds ultimate control over the film text.

Where the planning scenes deviate from historical record, there are also major discrepancies between the narratives of In the Name of the Father and Proved Innocent. In the Name of the Father's framing and authenticity claims hinge on the film narrative being perceived as authentic to the experiences of Gerry Conlon the real man who has had to live with the enduring trauma of being caught up in one of the greatest miscarriages of British justice in the twentieth century. Yet it can not be readily forgotten that the Gerry Conlon on screen is in all actuality a fictional character, a creation of Sheridan's cinematic imagination and expressed through the body of Daniel DayLewis. Any traces of reality that the film contains have been filtered not only through this fictional Conlon, but also through Conlon as he perceives and expresses himself through his written autobiography. Despite the way in which the film's claims of authenticity suppress the acknowledgement of these multiple versions of Conlon, each has lived a rather different experience. Of the narrative inconsistencies between autobiography and film, perhaps the most glaring is that where In the Name of the Father uses the months immediately preceding the Guildford pub bombing as its temporal origin point, the first several 
chapters of Proved Innocent, which amount to approximately $10 \%$ of the total book, are dedicated to exploring Conlon's early life in West Belfast. It is in Conlon's description of his childhood and adolescence where key aspects of his character and disposition are openly explored, from his street hustler attitude to work to his penchant for drug-taking, his distrust of violent politics and his strong but troubled commitment to his family. It is the book's early passages which detail Conlon's relationship with the local Provisional IRA that reveal the true preposterousness of the idea that he would be accepted as a Volunteer at any level of the organisation, let alone as part of a group entrusted with carrying out a high-profile and strategically important attack. Though the opening scenes of In the Name of the Father do touch on this relationship, the film seriously underplays its acrimoniousness. Conlon's appetite for mischief meant that from early adolescence he faced numerous run-ins with the group, including close calls with the punishment squads who considered themselves responsible for meting out the 'tough justice' of the Provisional IRA's 'community policing' programme. (McGartland, 2009: 49-52) It even got to the point that Conlon was compelled to join the movement's youth wing in the hopes that it would instil some discipline, but his continued anti-social behaviour meant that he was quickly expelled. (Conlon, 1993: 37) By eliminating Conlon's early years, In the Name of the Father neglects one of the most captivating, even if not entirely legally sound, arguments in support of his innocence: If when the stakes were high he had a proven track record of being less than cooperative with the organization, it is highly unlikely that in relatively lowstakes England the largely apolitical Conlon would be willing to plant bombs on behalf of the organisation which had caused him nothing but bother.

This being said, the film does make attempts to discuss Conlon's childhood through the lens of his relationship with his father Guiseppe while in prison. The strongest and most emotional of these scenes is that following Guiseppe's placement in the same remand cell as Conlon, itself a factual inaccuracy. In this scene Conlon releases his pentup childhood frustrations and chastises his father for following him to England in an expression of his guilt over what has become a shared tribulation. However, by constraining this discussion within the theme of parental sacrifice, (Farley, 2001: 203-211) In the Name of the Father does not give itself the narrative space to explore Conlon's roots in any more broadly meaningful way. By largely focusing on Conlon's time spent in the hands of the British 'justice' system, the film severely limits its ability to explore his relationship with other significant figures in his 
life. Though he avails himself of the 'closed' visits offered for Category A (maximum security) prisoners, these brief opportunities to speak to his mother and sisters are very closely monitored by prison staff. (Conlon, 1993: 160-163) Even privacy with regards to his post can not be expected. Thus, within the diegetic world of In the Name of the Father, the only other person with experiential knowledge of Conlon's early life with whom he can communicate openly is his father.

Yet the conditions put forward by the film are anything but natural and represent a rather significant deviation from Conlon's own account of events as provided in Proved Innocent. Firstly, the diegetic Gerry Conlon enjoys far greater access to his father than that enjoyed by his real-life counterpart. As Conlon frequently reminds the reader throughout his book, nearly every movement and moment of Category A prisoners are controlled by the prison authorities. While it is possible for one to have glimpses of shreds of freedom, there are mere glimpses barely tangible and always fleeting. Further Conlon and his father were very rarely in the same prison and indeed never enjoyed the privilege of sharing a cell, a detail which in itself poses a serious challenge to the film's claims of truthfulness and realism. (Conlon, 1993: 160; Barton, 2004: 169) Thus, in spite of the surface level appearance of events and conditions as 'naturally occurring', the circumstances by which the audience comes to learn of Conlon's early life are both artificial and deliberately manufactured. They reflect the spatio-temporal constraints around the diegesis set by Sheridan in accordance with his individual narrative focus, one which privileges the exploration of a melodramatic father-son relationship at the expense of historical accuracy, fidelity to the source material or a serious exploration of the broader social and political issues at play. (Barton, 2004: 170-171; Farley, 2001: 205-206) This in turn serves to highlight the way in which the perceptual diminishment of the role of the filmmaker can serve to undermine the film's claims to authenticity and, by extension, truthfulness and realism.

\section{Questions of Truth and Authenticity in Fifty Dead Men Walking}

As complicated as the relationship between voice, agency and authenticity is in In the Name of the Father, this relationship in Fifty Dead Men Walking is even more complex. This can be seen as a result of the more intensely contestable nature of the relationship between authenticity, truth and realism within the voice of the protagonist/ narrator than is the case with the earlier film. Fifty Dead Men Walking, the work of Ottawa, Canada's Kari Skogland, had a successful film festival run during the 2008 season which helped it to secure both 
international distribution in 2009 and critical recognition in the form of seven Genie Award nominations (including two wins). ${ }^{10}$ Both the film and the eponymous book which it claims as inspiration chart the career of Martin McGartand, a young working-class Catholic from West Belfast, as a police informant over the course of four years. Beginning in 1987 with his recruitment by the Royal Ulster Constabulary's Special Branch" ${ }^{11}$ at the age of 17 (though in the film he is presented as of legal age) to provide occasional photographic identification intelligence, the film follows McGartland as he infiltrates and rises through the ranks of the Provisional IRA, ${ }^{12}$ continuing to feed key operational information back to the police. (McGartland, 2009: 71) Fifty Dead Men Walking also covers his 1991 exposure which leads to his capture, torture and narrow escape from death at the hands of an infuriated Provisional IRA. Though brief, the film makes a foray into his subsequent life on the run where secrecy and movement is an absolute necessity as he is at constant risk of being found and killed by the organisation, a risk which becomes very real when he narrowly survives an additional assassination attempt while living in hiding. Where four years may be considered an extremely short career in most lines of work, the level of risk involved in being an informant (one which increases significantly the closer one moves to the pinnacle of the organisation) means that incontext McGartland's career was both notably lengthy and significant. (McGartland, 2009: 115-116)

In his investigation of the modern American biography, Timothy Dow Adams argues, "a promise to tell the truth is one of autobiography's earliest promises." (Adams, 1990: 9) However, promises are things which can be and easily are broken, a reality which runs throughout not only the remainder of Adams' work, but everyday life. In relation, J.P. Roos argues that, as far as authenticity is indissoluble from truthfulness and realism, "There is only one small

10 The Canadian equivalent of the Academy Awards (United States) or BAFTAs (United Kingdom). Fifty Dead Men Walking was awarded the 2010 Genie Awards in the 'Best Achievement in Art Direction/Production Design' and 'Best Screenplay, Adapted', while it was nominated for five additional awards including 'Best Motion Picture' and 'Best Direction'.

11 The Royal Ulster Constabulary (RUC) was the official police force of Northern Ireland from 1922 to 2000 when it was significantly reformed and renamed the Police Service of Northern Ireland (PSNI) as part of the peace process which followed the signing of the Good Friday Agreement in 1998 and the end of hostilities among the major combatants in the Troubles. Special Branch was the part of the organisation which was focused on intelligence and the subvention of threats to the state. (Ellison and Smith, 2000; Mulchay, 2006)

12 The Provisional Irish Republican Army (Provisional IRA, PIRA, Provos) was the largest separatist republican paramilitary group in the modern Northern Ireland conflict, responsible for more deaths than any other group in the conflict. (English, 2003: 379) 
problem: we cannot be sure whether the story is really authentic, that is, not only constructed as authentic but actually a true reflection of what the author has experienced and lived." (Roos, 2003: 34) It is largely impossible to know how accurate a work of autobiography is to personal experience insofar as inner thoughts and emotions are concerned. On the other hand, given that not all autobiographical material is related to these deep internal concerns, there is much of an autobiography which can be verified externally - dates of key events, names of parties involved etc. - with the understanding that the presentation of an autobiography to the world carries with it the likelihood that external verification of these details will be sought. This is a view adopted by Phillipe Lejeune who writes, "As opposed to all forms of fiction, biography and autobiography are referential texts: exactly like scientific or historical discourse, they claim to provide information about a 'reality' exterior to the text, and so to submit to a test of verification." (Lejeune, 1989: 22)

For both In the Name of the Father and the autobiographical text on which it was based, many of the details contained within are easily verifiable. With a core concern being the legal battles faced by the Guildford Four, the mountains of paperwork generated by the case provide a source of verification rarely found for other autobiographical material, a state of affairs that has meant the lambasting of the film from some critics for its many inaccuracies in its depiction of the legal case. (Mcllroy, 2001: 76) Yet, the availability of such rich historical material allows the trust generated by those elements of the film for which external verification can be sought to generate trust for those parts of the film, such as the planning scenes for the attack discussed above, which lack an 'official' record. Thus, albeit highly problematically, there is the sense that if Conlon (as inner, outer and external narrator) must at least be perceived to be telling 'the truth' about a large number of things, for he otherwise risks being exposed and discredited, in all likelihood he must be consistently truthful (or presenting events as he understands them to be true).

However, this is not a path to legitimacy that can easily be tread by Fifty Dead Men Walking as there is very little detail that can be externally verified. This means that the ability of the film to read as authentic, realistic and truthful resides in how much trust audiences are willing to invest in the McGartlands of both page and screen. Despite the existence of numerous archives and other efforts devoted to making publicly available a wealth of intelligence information about the Troubles, that McGartland was involved in what can be considered 
to be the later part of the conflict means that much information about the period in which he was active has yet to be released. Still, when and if any significant official information about McGartland's career were to enter the public domain, this information would only lead to a new verifiability for a very small number of the claims made by McGartland in his memoir or Skogland in her film. Because of the covert nature of his work, even if the British government were to suddenly allow unfettered access to all of its records relating to McGartland, this would still not go far enough given that much information, for the safety of all involved, likely went formally unrecorded. Given the embarrassment to the organization caused by a high-level infiltration, the Provisional IRA is even more unlikely to be forthright in providing information about McGartland, a man who must continue to live life on the run despite the organisation formally standing down in 2005. With substantial external verification of details provided by McGartland in his autobiography unlikely, the authenticity (and truthfulness in particular) of Skogland's film text rests upon how well the 'real' McGartland is able to convince that his autobiography is both truthful and forthright. More abstractly put, assertions that Fifty Dead Men Walking is rooted in a 'true story' hinge upon the reliability of its protagonist's reallife counterpart. This is a reliability which can, in turn, exclusively be established through this counterpart's own autobiographical writings, creating a situation of near paradoxical self-verification. While through Proved Innocent, Gerry Conlon is responsible for the verification of a number of the claims made by In the Name of the Father, the existence of opportunities for external verification means that this film is able to escape such paradoxical exclusivity.

As has already been discussed, McGartland is no 'ordinary' narrator (or protagonist). The authenticity of his narrative depends on experiential knowledge of largely unverifiable events, yet at the same time his involvement in the events described in his memoir is precipitated by his ability to act disingenuously. As a result, the decision of whether McGarland's autobiography can be trusted rests with each individual reader, a conundrum for Skogland's audience as well. Difficult to make at the level of the autobiography where events and details are only filtered through McGartland who is able to exercise a level of agency which nears the unmediated, this decision becomes even more difficult when one considers the meditational role played by the filmmaker in adapting this life for screen. Fifty Dead Men Walking is thus asking its audience to put their faith in a Martin McGartland who is a representation of a Martin McGartland who is a representation of the Martin McGartland. One cannot help but be 
more than a little suspicious of how much of what is 'true' is stripped away from as one moves farther and farther away from the man who successfully managed a double life for years before being forced into life in hiding. It would be difficult to argue that Skogland is unaware of the challenge she faces in making strong enough claims to authenticity to lend her film legitimacy as a public narrative of the Troubles. Instead, Skogland displays a keen ability to match balance the need for her film to engage in an authentic discourse of events with avoidance of the full force of the burden of reliability that comes with the questionable truthfulness of the source narrative, by subtly claiming Fifty Dead Men Walking to be 'inspired by' as opposed to 'based on' McGartland's memoir. Whereas In the Name of the Father's authenticity claims take on something more akin to absolutism through the combination of Sheridan's explicit use of 'based upon' and a frame story, Skogland actively minimises her claims to the bare minimum required for viable legitimacy as strong claims of authenticity and truthfulness risks the loss of the audience trust in the narrative needed for the narrative to work.

With two simple words, 'inspired by', Skogland grants herself as director, and Fifty Dead Men Walking as film text, greater artistic license than would have been possible with the use of 'based on'. Thus there is more acceptable room for creativity, invention, and deviation from 'fact' in Fifty Dead Men Walking than with a film such as In the Name of the Father where claims of authenticity are less subtle. How can such a slight semantic shift mean so much? As Stephen N Lipkin explains:

To codify the issue of proximity, the industry recognizes two basic categories of material: docudramas "based on" their referents and those "inspired by" actual people and occurrences. Stories 'based on' true events have closer proximity to their subjects and are governed by stricter legal guidelines than stories that are 'inspired by' their sources. (Lipkin, 2002: 57)

Where those film narratives which employ 'based upon' are bound by the conditions of the 'life rights' agreed to between the subject of a biographical film and the filmmaker, for those filmmakers who use 'inspired by' this adherence is looser, if not often optional. (Lipkin, 2002: 57) That in changing two words on a title card, a film's legal standing and responsibilities can be altered is an exemplification of the ultimate power over the final film product held by the author of the film text. Skogland choice of 'inspired by' to cover the relationship of her film with its source text also illustrates the degree to which McGartland's agency can be expected to be mediated within Fifty Dead Men Walking the film. 


\section{Conclusion}

There are numerous similarities between Irish filmmaker Jim Sheridan's In the Name of the Father and Fifty Dead Men Walking by Canadian filmmaker Kari Skogland. At a surface level, both films seek to develop an understanding of key events in the period of Northern Irish history known as the Troubles, engaging seriously with the political violence within and stemming from the region. By the standards of films dealing with the Troubles, both also achieved a considerable degree of success. At the narrative level, In the Name of the Father and Fifty Dead Men Walking also share a reliance on the written autobiographical material of their protagonists to fuel their claims of authenticity. This use of local autobiographical material is of particular importance as neither Sheridan nor Skogland, by virtue of being outsiders in the context of the Troubles, carry the proximity to events that would allow their narratives to carry an embedded (or automatic) authenticity.

The authenticity claims made by these films are wrapped up in the film texts' claims of truthfulness and the realism of their interpretations of events. Yet, with both films the local voices which underpin their claims to authenticity, truth and reality (essential to the legitimacy of narrative engagement with the Troubles) have their agency limited and controlled by the filmmakers who depend upon them. Where representation is collaborative and the represented have what they perceive as an active role in their representation, there is a recognition that in exchange for the opportunity to have their voice reach a larger audience there must be a ceding of ultimate authority over their representation to the filmmaker. with an acknowledgement of the risk that they may be misrepresented. However, in the films examined here, the adaptation of autobiography material to the screen can be seen as an inactive representation where collaboration is much more limited than in other modes of Troubles filmmaking. While both Gerry Conlon and Marting McGartland have had the capacity to shape and define their self-representation as manifested in their written autobiographies, these works exist as 'complete' representations and do not represent an ongoing engagement with their representations as their autobiographical selves are translate to screen.

Though the mediation of agency discussed here is not intrinsically negative, the way in which In the Name of the Father and Fifty Dead Men Walking obscure the process can be seen to weaken the overall strength of these films' claims to authenticity, truth and reality. At the same time, this does not necessarily mean that these 
films will not overtake 'official' or alternative narratives as the public history of the events, as there is a case to be made that it is the fictional Gerry Conlon as embodied in Daniel Day-Lewis and presented in In the Name of the Father who has become the definitive 'Gerry Conlon' at the expense of his real-life counterpart. Yet, to argue that a fictional narrative such as that presented in In the Name of the Father can dominate public discourse of events is rather different from arguing that it does so with any degree of legitimacy. As is the case with both films, weakened authenticity undermines their ability to resist the type of strong criticisms that could prevent these narratives from retaining an enduring legitimacy.

The claims made by In the Name of the Father are more resolute than those made by Fifty Dead Men Walking. As a result, major inconsistencies between the film narrative and the autobiography on which it is based prevent the audience from developing a full understanding of Gerry Conlon's experience of injustice, challenging and ultimately undermining its authenticity claims. With Fifty Dead Men Walking, the claims to authenticity made by Skogland are not undermined by the contents of the film so much as they are deliberately limited by Skogland at its outset. This serves as a recognition of the complexity of asking one's audience to trust in a narrative which claims to be a representation of another narrative which in turn claims to be based on real events. Though in other circumstances, the relationship between real events and the first link in this narrative chain is considered to be an authentic one, the unverifiability of the events concerned and the potential unreliability of McGartland as autobiographical author mean that in fact quite a lot of blind trust is being requested of Fifty Dead Men Walking's audience. But blind trust is difficult to come by, and it becomes necessary for Skogland to avail herself of a lower level of claim to authenticity and truth. It is in making the intricacies of the frequently flawed working relationship between authorship, authenticity and agency visible that it becomes possible to understand how not only these two films but also the entire body of Troubles-related films have privileged certain understandings of truth and reality. Perhaps most importantly of all, in bringing the power relationship between authors and those that they represent out from behind the cinema screen, an understanding of the limitations of agency, authenticity and 'realism' in narrative cinema can be developed more generally.

\section{Bibliography}

Adams, Timothy Dow. Telling Lies in Modern American Autobiography. Chapel Hill: University of North Carolina Press, 1990. 
Barton, Ruth. Irish National Cinema. New York: Routledge, 2004.

Beaty, Bart. "Autobiography as Authenticity." In A Comic Studies Reader, edited by Jeet Heer and Kent Worcester, 226-235. Jackson: University Press of Mississippi, 2009.

Bew, Paul, Peter Gibbon and Henry Patterson. Northern Ireland 1921 - 2001: Political Power and Social Classes. London: Serif, 2002.

Bew, Paul and Gordon Gillespie. Northern Ireland: A Chronology of the Troubles 19681998. Dublin: Gill \& Macmillan, 1999.

Blaney, Aileen. "Remembering Historical Trauma in Paul Greengrass' Bloody Sunday." History and Memory 19, no 2 (2007): 113-138.

Caughie, John, Ed. Theories of Authorship. New York: Routledge, 1981.

Coleman, Peter T. "Characteristics of Protracted, Intractable Conflict: Toward the Development of a Metaframework-I." Peace and Conflict: Journal of Peace Psychology 9, no. 1 (2003): 1-37.

Conlon, Gerry. In the Name of the Father (originally published as 'Proved Innocent'). London: Plume, 1993.

Conway, Brian. "Active Remembering, Selective Forgetting, and Collective Identity: The Case of Bloody Sunday." Identity: An International Journal of Theory and Research 3, no 4 (2003): 305-323.

Corrigan, Tim. "The Commerce of Auteurism." In Film and Authorship, edited by Virginia Wright Wexman, 96-111. New Brunswick: Rutgers University Press, 2003.

Darby, John. "Conflict in Northern Ireland: A Background Essay." In Facets of the Conflict in Northern Ireland, edited by Seamus Dunn, 15-23. London: Macmillan, 1995.

Dawson, Graham. Making Peace With the Past?: Memory, Trauma and the Irish Troubles. Manchester University Press, 2007.

Donnelly, K. J. "The Policing of Cinema: Troubled Film Exhibition in Northern Ireland." Historical Journal of Film, Radio and Television 20, no. 3 (2000): 385-396.

Ellison, Graham and Jim Smyth. The Crowned Harp: Policing Northern Ireland. London: Pluto Press, 2000.

English, Richard. Armed Struggle: The History of the IRA. London: Macmillan, 2003.

Farley, Fidelma. "In the Name of the Family: Masculinity and Fatherhood in Contemporary Northern Irish Films." Irish Studies Review 9, no 2 (2001): 203-213.

Ferri, Anthony J. Willing Suspension of Disbelief: Poetic Faith in Film. Plymouth: Lexington Books, 2007.

Gillespie, Gordon. A Short History of the Troubles. Dublin: Gill and Macmillan, 2010.

Golden-Biddle, Karen and Karen Locke. "Appealing Work: An Investigation of How Ethnographic Texts Convince." Organizational Management 4, no. 4 (1993): 595-616.

Herlihy, David. "Am I a Camera? Other Reflections on Films and History." The American Historical Review 93, no. 5 (1988): 1186-1192.

Hess, John. "La politique des auteurs, 2: Truffaut's Manifesto." Jump Cut: A Review of Contemporary Media 2 (1974): 20-22.

Higashi, Sumiko. "Walker and Mississippi Burning: Postmodernism versus Illusionist Narrative." In Revisioning History: Film and the Construction of a New Past edited by Robert A Rosenstone, 188-201. Princeton: Princeton University Press, 1995.

Hill, John. Cinema and Northern Ireland: Film, Culture and Politics. London: British Film Institute, 2006.

Hills, Matt. Fan Cultures. London: Routledge, 2002.

Hollows, Joanne. "Mass Culture Theory and Political Economy." In Approaches to Popular Film, edited by Joanne Hollows and Mark Jancovich, 15-36. Manchester: Manchester University, Press, 1995.

Lejeune, Phillipe. On Autobiography. Trans. Katherine Leary. Minneapolis: University of Minnesota Press, 1989.

Lipkin, Steven N. Real Emotional Logic: Film and Television Docudramas as Persuasive Practice. Carbondale: University of Illinois Press, 2002. 
McGartland, Martin. Fifty Dead Men Walking: The Heroic True Story of a British Secret Agent Inside the IRA. London: John Blake Publishing, 2009.

Mcllroy, Brian. Shooting to Kill: Filmmaking and the "Troubles" in Northern Ireland. Richmond: Stevenson Press, 2001.

McLoone, Martin. Irish Film: The Emergence of a Contemporary Cinema. London: British Film Institute, 2006.

McKittrick, David, Seamus Kelters, Brian Feeny, Chris Thornton and David McVea. Lost Lives: The stories of the men, women and children who died as a result of the Northern Ireland troubles. Edinburgh: Mainstream Publishing, 2001.

McKittrick, David and David McVea. Making Sense of the Troubles. Toronto: Penguin, 2012.

Metz, Christian. Film language: A semiotics of the cinema. Translated by Michael Taylor. The Hague: Mouton, 1974.

Moore, Ryan. Sells Like Teen Spirit: Music, Youth Culture and Social Crisis. New York: New York University Press, 2010.

Morgan, Winifred. "Frame Narrative." In The Companion to Southern Literature: Themes, Genres, Places, People, Movements and Motifs edited by Joseph M Flora and Lucinda H MacKethan, 282-283. Baton Rouge: Louisiana State University Press, 2002.

Mulchay, Aogán. Policing Northern Ireland: Conflict, Legitimacy and Reform. Devon: Willan Publishing, 2006.

Mulholland, Marc. Northern Ireland: A Very Short Introduction. Oxford: Oxford University Press, 2002.

Nunes, Charlotte. "In the Name of National Security: Torture and Imperialist Ideology in Sheridan's In the Name of the Father and Jordan's Breakfast on Pluto." Human Rights Quarterly 31, no. 4 (2009): 916-933.

O'Leary, John. Reflections on Fenians and Fenianism, Volume I. London: Downey and Company, 1896.

Oppenheimer, A R. IRA: The Bombs and the Bullets - A History of Deadly Ingenuity. Dublin: Irish Academic Press, 2009.

Pettitt, Lance. Screening Ireland: Film and Television Representation. Manchester: Manchester University Press, 2000.

Richards, Jeffrey. "Film as an historical source." In The Contemporary History Handbook, edited by Brian Brivati, Julia Buxton and Anthony Seldon, 394-407. Manchester: Manchester University Press.

Roos, J.P. "Context, Authenticity, Referentiality, Reflexivity: Back to Basics in Autobiography." In Biographical Research in Eastern Europe: Altered Lives and Broken Biographies edited by Robin Humphrey, Robert Miller and Elena Zdravomyslova, 27-38. London: Ashgate, 2003.

Rose, Peter. Making Sense of the Troubles. New York: Palgrave Macmillan, 2001.

Rosenstone, Robert A. History of Film/Film on History. Harlow: Pearson Education, 2006.

Saville, Right Honourable Lord. Principal Conclusions and Overall Assessment of the Bloody Sunday Inquiry. London: Stationary Office, 2010.

Smith, David A and Gerald Chambers. Inequality in Northern Ireland. Oxford: Clarendon Press, 1991.

Smithey, Lee. "Conflict Transformation, Cultural Innovation, and Loyalist Identity in Northern Ireland." In Culture and Belonging in Divided Societies: Contestation and Symbolic Landscapes, edited by Marc Howard Ross, 85-106. Philadelphia: University of Pennsylvania Press, 2009.

Stam, Robert, Robert Burgoyne and Sandy Fitterman-Lewis. New Vocabularies in Film Semiotics: Structuralism, Post-Structuralism and Beyond. London: Routledge, 1996.

Sutherland, Heather. " 'Embedded' actors as markers of authenticity: Acting the real in 'Troubles' docudramas." Studies in Documentary Film 4, no. 3 (2010): 267-281. 
Tonge, Jonathan. Northern Ireland. Cambridge: Polity Press, 2006.

Wertsch, James V. and Leslie J. Rupert. "The Authority of Cultural Tools in a Sociological Approach to Mediated Agency." Cognition and Instruction 11, no. $3 / 4$ (1993): 227-239.

Whaley Eager, Paige. From Freedom Fighters to Terrorists: Women and Political Violence. Aldershot: Ashgate, 2008.

White, Hayden. "The Value of Narrativity in the Representation of Reality." Critical Inquiry 7, no. 1 (1980): 5-27.

Whyte, John. Interpreting Northern Ireland. Oxford: Clarendon Press, 1990. 